Article

\title{
Magnetic Combined Cross-Linked Enzyme Aggregates of Ketoreductase and Alcohol Dehydrogenase: An Efficient and Stable Biocatalyst for Asymmetric Synthesis of (R)-3-Quinuclidinol with Regeneration of Coenzymes In Situ
}

\author{
Yuhan Chen ${ }^{1}$, Qihua Jiang ${ }^{1}$, Lili Sun ${ }^{1}$, Qiang Li ${ }^{2}$, Liping Zhou ${ }^{1}$, Qian Chen ${ }^{1}$, Shanshan Li ${ }^{1}$, \\ Mingan $\mathrm{Yu}^{1}$ and Wei $\mathrm{Li}^{1,3}$,* \\ 1 Department of Medicinal Chemistry, School of Pharmacy, Chongqing Medical University, \\ Chongqing 400016, China; chenyuhan233@outlook.com (Y.C.); 100877@cqmu.edu.cn (Q.J.); \\ sunlltxc@126.com (L.S.); zhoulpbox@163.com (L.Z.); cqdyx629@outlook.com (Q.C.); \\ ldsmm0910@outlook.com (S.L.); minganyu666@outlook.com (M.Y.) \\ 2 Chongqing Key Laboratory of Medicinal Resources in the Three Gorges Reservoir Region, School of \\ Biological \& Chemical engineering, Chongqing University of Education, Chongqing 400067, China; \\ sxliqiang_826@163.com \\ 3 Chongqing Key Laboratory of Biochemistry and Molecular Pharmacology, Chongqing Medical University, \\ Chongqing 400016, China \\ * Correspondence: li_wei@cqmu.edu.cn; Tel.: +86-23-6848-5161
}

Received: 14 July 2018; Accepted: 30 July 2018; Published: 15 August 2018

\begin{abstract}
Enzymes are biocatalysts. In this study, a novel biocatalyst consisting of magnetic combined cross-linked enzyme aggregates (combi-CLEAs) of 3-quinuclidinone reductase (QNR) and glucose dehydrogenase $(\mathrm{GDH})$ for enantioselective synthesis of $(R)$-3-quinuclidinolwith regeneration of cofactors in situ was developed. The magnetic combi-CLEAs were fabricated with the use of ammonium sulfate as a precipitant and glutaraldehyde as a cross-linker for direct immobilization of QNR and GDH from E. coli $\mathrm{BL}(21)$ cell lysates onto amino-functionalized $\mathrm{Fe}_{3} \mathrm{O}_{4}$ nanoparticles. The physicochemical properties of the magnetic combi-CLEAs were characterized by Fourier transform infrared spectroscopy (FTIR), X-ray diffraction (XRD) and magnetic measurements. Field emission scanning electron microscope (FE-SEM) images revealed a spherical structure with numerous pores which facilitate the movement of the substrates and coenzymes. Moreover, the magnetic combi-CLEAs exhibited improved operational and thermal stability, enhanced catalytic performance for transformation of 3-quinuclidinone $(33 \mathrm{~g} / \mathrm{L})$ into $(R)$-3-quinuclidinol in $100 \%$ conversion yield and $100 \%$ enantiomeric excess (ee) after $3 \mathrm{~h}$ of reaction. The activity of the biocatalysts was preserved about $80 \%$ after 70 days storage and retained more than $40 \%$ of its initial activity after ten cycles. These results demonstrated that the magnetic combi-CLEAs, as cost-effective and environmentally friendly biocatalysts, were suitable for application in synthesis of $(R)$-3-quinuclidinol essential for the production of solifenacin and aclidinium with better performance than those currently available.
\end{abstract}

Keywords: enzyme immobilization; magnetic nanoparticles; combined cross-linked enzyme aggregates; reuse; $(R)$-3-quinuclidinol 


\section{Introduction}

Enantiomerically pure or enriched alcohols with excellent enantiomeric excess (ee) are highly valuable chiral building blocks for the production of wide range fine chemicals, agrochemicals and particularly pharmaceuticals [1-3]. For instance, $(R)$-3-quinuclidinol is a key chiral intermediate of many drugs such as aclidinium bromide [4], solifenacin succinate [5] and revatropate [6]. Aclidinium and revatropate are anticholinergic for long-term management of chronic obstructive pulmonary disease (COPD) which leads to more than 3 million deaths worldwide every year [7] and is also the third leading cause of death in United States following cancer and heart disease. Solifenacin, a competitive muscarinic receptor antagonist which attenuates bladder contraction, was approved in 2004 to treat overactive bladder (OAB) in the USA and the EU [8]. Recently published studies showed that when clinical benefits and risks are considered, aclidinium and tiotropium generate similar value to COPD patients, but when considering convenience criteria, aclidinium may be preferred [9].

(R)-3-Quinuclidinol can be synthesized by resolution of racemic mixtures of (dl)-3-quinuclidinone or by chemical, biocatalytic asymmetric synthesis. Chemical synthesis is frequently used to synthesize $(R)$-3-quinculidinol. For instance, asymmetric hydrogenation of 3-quinuclidinone using $\operatorname{RuBr} 2[(S, S)$-xylskewphos](pica) as chiral catalysts in a base containing ethanol has given $(R)-3$-quinuclidinol in 88-90\% ee [10]. After that, a much better result, $(R)$-3-quinuclidinol in $97-98 \%$ ee, was obtained under the synergistic catalysis of $\mathrm{RuCl}_{2}\left[(S)\right.$-binap][(R)-iphan] and $\mathrm{t}-\mathrm{C}_{4} \mathrm{H}_{9} \mathrm{OK}$ [11] . However, these methods suffer from several limitations. The metal catalysts are expensive, toxic, and the transition metal may contaminate the product. An alternative access to $(R)$-3-quinuclidinol in $42 \%$ overall yield and $96 \%$ ee is Aspergillus melleus protease-catalyzed kinetic resolution of (dl)-3-quinuclidinol esters [12]. Nevertheless, no chemical or resolution of racemic compounds can compare with the biocatalytic asymmetric reduction of 3-quinuclidinone, in which biocatalysts produce the products in $100 \%$ theoretical conversion yield and exceptionally high ee value. Furthermore, biocatalysts can operate under milder and more environmentally friendly conditions than the traditional chemical synthesis methods, thus avoiding using more severe conditions which can lead to problems with isomerization, racemization and rearrangement $[13,14]$. The biocatalyst can be a newly isolated Nocardia sp. and Rhodococcus erythropolis [15] or a screened fungal system belonging to Mucor piriformis [16], or a recombinant ketoreductase [17,18]. Nevertheless, the real breakthrough in biocatalysts came from the development of recombinant DNA technology $[19,20]$. However, more notable is that enzyme immobilization contributed to facilitating the progress of practical industrial applications of biocatalysts and recycling for long periods of time [20]. Unfortunately, most enzyme immobilization techniques have required a purified enzyme [21-23], but such processes are often too costly and low-yielding [24-26]. In particular, it is difficult to purify the low concentration of extracellular enzymes, which is often produced in cell culture medium [27]. Currently, coupling the purification and immobilization steps by nickel column may be a strategy to design a selective immobilization process for his-tagged protein [28-30], but the nickel column is expensive and needs to be regenerated after running about three times, and the purity of his-tagged protein was low [28]. Hence, there is a need to develop a simple and cost-effective immobilization technique for the biosynthesis of $(R)$-3-quinuclidinol in high yields and high optical purity and in situ recycling of cofactors.

A substantial effort has been applied to the development of effective immobilization strategies to improve the long-term operational stability of enzyme and to facilitate its efficient recovery and recycling [31,32]. Cross-linked enzyme aggregates (CLEAs) may be a potential method for enzyme immobilization due to clear advantages: high volumetric productivity, superior storage stability, amenability for easy scaling-up and excellent recyclability, especially the method does not require purified enzyme and can be employed for the direct immobilization of an enzyme from crude cell lysate [31-33]. CLEAs can be simply prepared by precipitating enzyme solution at the optimum $\mathrm{pH}$ by addition of organic solvents or inorganic salts, and then cross-linked by a bifunctional cross-linking agent, such as glutaraldehyde (GA). As a result, the cross-linking 
increases the chance that any multi-subunit enzyme was cross-linked to another component of the biocatalyst, avoiding enzyme dissociation and contributing to stabilizing the quaternary structure of enzyme [34]. So far, several enzymes including penicillin G amidase, alcalase, hydrolases, oxidoreductases, lyases, esterases, etc. have been successfully immobilized as CLEAs with high specific activity and activity recovery $[31,32,35]$. Interestingly, combined cross-linked enzyme aggregates (combi-CLEAs) are a novel prospect for co-immobilization of two or more enzymes, which can catalyze various cascade and non-cascade bioconversion processes [36]. For example, acombi-CLEAs of glucose dehydrogenase (GDH) and ketoreductase were developed and employed repeatedly in the reduction of ethyl 4-chloro-3-oxobutanoate to syntheses the key atorvastatin intermediate ethyl 4-chloro-3-hydroxybutyrate [37]. A significant advantage of combi-CLEAs is a robust regeneration system for cofactors, the improved $\mathrm{pH}$ and thermal stability, high concentration of substrate tolerance, long-term operational stability and reusability, allowing its uses at relatively extreme conditions than the soluble counterparts. The authors believed that the strategy could be widely applied to produce various chiral alcohols with high efficiency and low cost [37]. However, it is difficult to deal with and fully recover the combi-CLEAs particles due to it forming clumps leading to internal mass-transfer limitations during conventional centrifugation or filtration treatments [38-40]. In a further elaboration, the smart magnetic CLEAs were prepared by cross-linking of enzyme aggregates onto magnetic nanoparticles (MNPs) [40,41]. Due to the magnetic nature, the magnetic biocatalysts can be easily separated from reaction mixture by an external magnet without the need for a filtration or centrifugation step, thus overcoming the disadvantage of squeezing of the CLEAs, and can be employed in a magnetically stabilized fluidized bed reactor, giving novel combinations of biotransformations and downstream processing [31,32]. However, the application of MNPs still has some disadvantages including aggregation, stability, leaching, and toxicity [42,43]. Usually, these problems can be circumvented by coating a layer of inert silica onto the surface of MNPs. Moreover, the surface of silica coated MNPs can be further functionalized with 3-aminopropyl trimethoxysilane (APTES) [44,45].

To our knowledge, application of amine functionalized silica coated MNPs for the preparation of combi-CLEAs remain scarcely investigated. Therefore, the aim of this study is to develop the magnetic combi-CLEAs of 3-quinuclidinone reductases (QNR) and glucose dehydrogenase (GDH) for enantioselective synthesis of (R)-3-quinuclidinol with regeneration of coenzymes in situ. The magnetic combi-CLEAs were prepared by co-precipitation of amine functionalized-MNPs, QNR and GDH from E. coli $\mathrm{BL}(21)$ cell lysates by agents such as $\left(\mathrm{NH}_{4}\right)_{2} \mathrm{SO}_{4}$ to form aggregates, followed by cross-linking the aggregates using bifunctional agents such as GA. The physicochemical properties of the resulting biocatalyst were carried out by Fourier transform infrared spectroscopy (FTIR), X-ray diffraction (XRD), vibrating sample magnetometer (VSM), transmission electron microscopy (TEM) and field emission scanning electron microscope (FE-SEM). To permit retention of significant levels of enzyme activity, the effects of precipitant agents, cross-linker concentration, $\mathrm{pH}$ and temperature on the enzyme activity were optimized. The storage stability, reactivity, reusability and characteristic morphological changes of during recycling of the biocatalysts were also tested.

\section{Results}

\subsection{Preparation and Characterization of the Magnetic Combi-CLEAs of QNR and GDH}

The fragment of the $q n r$ gene encoding QNR and $g d h$ gene encoding GDH with endogenous promoter and ribosomal recognition sequences has been inserted into $\mathrm{pET} 28 \mathrm{a}$ to give $\mathrm{pET} 28 \mathrm{a}-\mathrm{QNR}$ and pET28a-GDH. Optimized cultivation conditions including a low expression temperature of $25^{\circ} \mathrm{C}$ for $48 \mathrm{~h}$ and the presence of $0.2 \mathrm{mM}$ isopropyl $\beta$-D-Thiogalactoside (IPTG) afforded a similar cell stability of the cells expressing the QNR and GDH compared to the host strain E. coli BL(21) (Figure 1). A very significant band appeared at $25.70 \mathrm{kDa}$ and $28.25 \mathrm{kDa}$ in accordance with the calculated molecular weight derived from the amino acid sequence of the full QNR and GDH. 


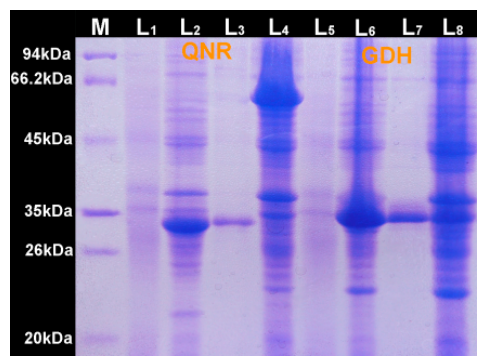

Figure 1. 12\% SDS-PAGE gel of protein samples. Lane M, protein molecular weight markers; Lane 1 to Lane 4, Lane 5 to Lane 8 for the E. coli (His-QNR), E. coli (His-GDH) before induction, after induction, the cell lysate supernatant and the cell lysate precipitate, respectively.

Magnetic combi-CLEAs of QNR-GDH biocatalyst preparation involves a sequence of two physic-chemical steps starting with co-precipitation of QNR, GDH and $\mathrm{Fe}_{3} \mathrm{O}_{4} @ \mathrm{SiO}_{2}-\mathrm{NH}_{2}$ nanoparticles followed by cross-linking the enzyme aggregates with themselves and $\mathrm{NH}_{2}$ - attached on the surfaces of $\mathrm{Fe}_{3} \mathrm{O}_{4} @ \mathrm{SiO}_{2}-\mathrm{NH}_{2}$ nanoparticles (Scheme 1), where $\mathrm{Fe}_{3} \mathrm{O}_{4} @ \mathrm{SiO}_{2}-\mathrm{NH}_{2}$ were employed as support for enzyme immobilization. For this purpose, we first synthesized magnetic $\mathrm{Fe}_{3} \mathrm{O}_{4}$ nanoparticles. The nanoparticles were then coated with tetraethylorthosilicate (TEOS) followed by functionalizing with APTES in alkaline conditions, thus preventing these nanoparticles from clustering and improving their chemical stability. The resultant $\mathrm{Fe}_{3} \mathrm{O}_{4} @ \mathrm{SiO}_{2}-\mathrm{NH}_{2}$ nanoparticles were mixed with cell lysates containing QNR and GDH. After precipitation and cross-linking under the optimized conditions such as precipitant agents, cross-linker concentration and the cross-linking time, the magnetic combi-CLEAs were obtained. To ensure successful preparation of magnetic combi-CLEAs, FTIR, XRD and FE-SEM were employed to confirm these results.

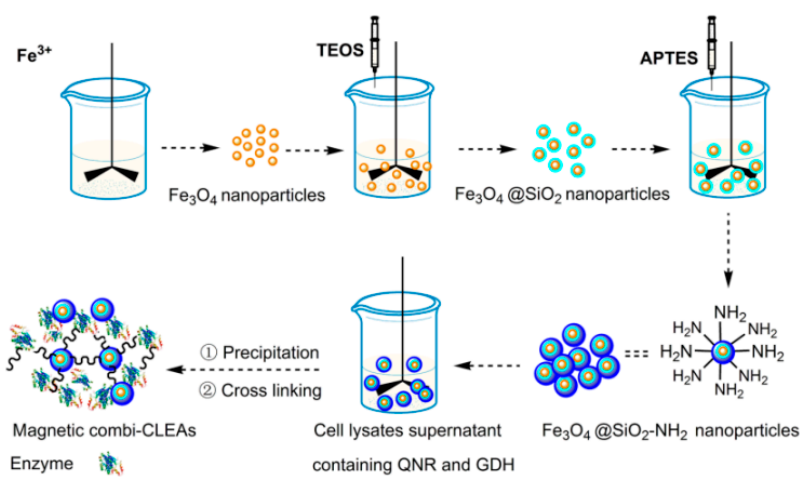

Scheme 1. The diagram of the preparation of the magnetic combi-CLEAs biocatalysts.

Firstly, FTIR analyses was carried out to detect the functional groups of $\mathrm{Fe}_{3} \mathrm{O}_{4}, \mathrm{Fe}_{3} \mathrm{O}_{4} @ \mathrm{SiO}_{2}-\mathrm{NH}_{2}$, free enzyme and magnetic combi-CLEAs. As can be seen form Figure 2A(a), the absorption peak at $578 \mathrm{~cm}^{-1}$ was attributed to the Fe-O bond stretching vibration, and the characteristic peak also appeared in Figure $2 \mathrm{~A}(\mathrm{~b}, \mathrm{~d})$, indicative of no changes in the structure of $\mathrm{Fe}_{3} \mathrm{O}_{4}$ after chemical modification. The peaks about at $3410 \mathrm{~cm}^{-1}$ and $1627 \mathrm{~cm}^{-1}$ were associated with-OH groups available from the surface of $\mathrm{Fe}_{3} \mathrm{O}_{4}$. In the $\mathrm{Fe}_{3} \mathrm{O}_{4} @ \mathrm{SiO}_{2}-\mathrm{NH}_{2}$ spectrum, the peaks at 465, 790, 940 and $1092 \mathrm{~cm}^{-1}$ were assigned to the O-Si-O bending vibration, $\mathrm{Si}-\mathrm{O}-\mathrm{Si}$ symmetric, Si-O symmetric and Si-O-Si asymmetric stretching vibration of the coated silica shell, respectively. The broad band at 3400-3500 $\mathrm{cm}^{-1}$ can be ascribed to the characteristic peaks of $\mathrm{NH}_{2}{ }^{-}$groups of APTES which were overlain by hydroxyl groups stretching vibrations. The peaks at $2930 \mathrm{~cm}^{-1}$ corresponds to- $\mathrm{CH}_{2}$ bond stretching vibrations of aminopropyl from APTES [44]. The results demonstrated that $\mathrm{Fe}_{3} \mathrm{O}_{4} @ \mathrm{SiO}_{2}$ nanoparticles were successfully modified by APTES (Figure 2A(b)). FTIR spectrum of QNR and GDH before (Figure 2A(c)) and after immobilization (Figure 2A(d)) presented changes in the characteristic 
peaks of functional groups. Especially decreasing of intensity at 1500 and $1550 \mathrm{~cm}^{-1}$ correspond to $\mathrm{N}-\mathrm{H}$ vibration of free enzymes indicated that the $\mathrm{NH}_{2}{ }^{-}$group of QNR and GDH reacted with the $\mathrm{NH}_{2}{ }^{-}$group attached on $\mathrm{Fe}_{3} \mathrm{O}_{4} @ \mathrm{SiO}_{2}$ by GA cross-linking. XRD was used to identify the crystalline structure of all samples. As can be seen in Figure 2B, the bare $\mathrm{Fe}_{3} \mathrm{O}_{4}$ exhibited characteristic crystalline peaks at around $30.40^{\circ}, 35.80^{\circ}, 43.60^{\circ}, 53.70^{\circ}, 57.20^{\circ}$ and $62.70^{\circ}$, which are consistent with the standard $\mathrm{Fe}_{3} \mathrm{O}_{4}$ XRD data (JCPDS, card 89-0950) [46]. In addition, it was found (Figure 2B(c)) that the coating procedure did not affect the phase change of $\mathrm{Fe}_{3} \mathrm{O}_{4}$ nanoparticles because the $\mathrm{SiO}_{2}$ and APTES coatings are amorphous. Therefore, new peaks attributable to these groups could not be detected by XRD analysis. For free enzyme (Figure 2B(a)), their trends were similar to the XRD of the magnetic combi-CLEAs (Figure 2B(d)). Nevertheless, the crystallinity of the samples was clearly decreased after the coating or / and immobilization process (Figure $2 \mathrm{~B}(\mathrm{c}, \mathrm{d})$ ), mainly due to the partial destruction of the regularity of the $\mathrm{Fe}_{3} \mathrm{O}_{4}$ crystal structure after coating with a silica shell and APTES and subsequently subjected to the GA cross-linking procedure.
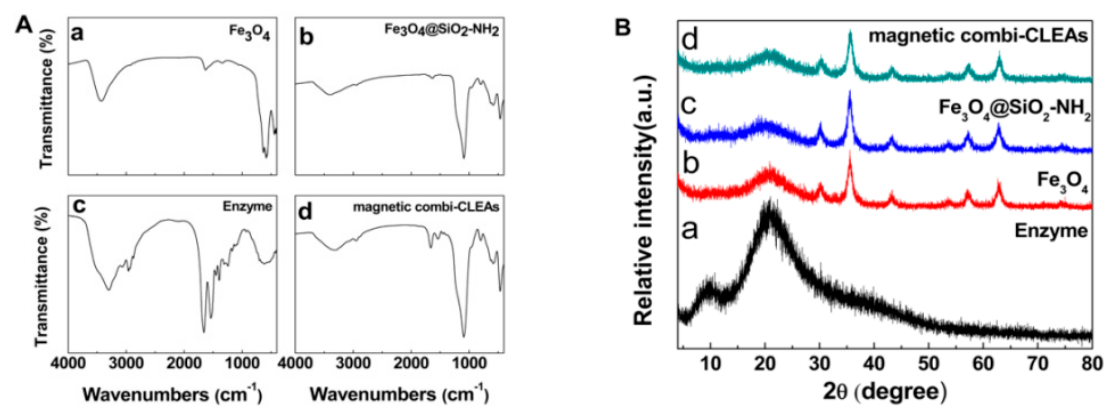

Figure 2. (A) FTIR spectra of (a) $\mathrm{Fe}_{3} \mathrm{O}_{4}$; (b) $\mathrm{Fe}_{3} \mathrm{O}_{4} @ \mathrm{SiO}_{2}-\mathrm{NH}_{2}$; (c) free enzyme; (d) magnetic combi-CLEAs. (B) XRD of (a) free enzyme; (b) $\mathrm{Fe}_{3} \mathrm{O}_{4}$; (c) $\mathrm{Fe}_{3} \mathrm{O}_{4} @ \mathrm{SiO}_{2}-\mathrm{NH}_{2}$; (d) magnetic combi-CLEAs.

The magnetic behaviors were confirmed by the magnetization curves (Figure 3a), which were typical plot of magnetization against applied magnetic field ( $\mathrm{M}-\mathrm{H}$ loop) at room temperature, and crossed the zero point, inductive of the superparamagnetic properties. The saturation magnetization value of $\mathrm{Fe}_{3} \mathrm{O}_{4} @ \mathrm{SiO}_{2}-\mathrm{NH}_{2}$ and magnetic combi-CLEAs was about $66.79 \mathrm{emu} / \mathrm{g}$ and $40.88 \mathrm{emu} / \mathrm{g}$, respectively. The decreased superparamagnetic behaviors of the magnetic combi-CLEAs could be explained due to cross-linking of proteins on the surface of $\mathrm{Fe}_{3} \mathrm{O}_{4} @ \mathrm{SiO}_{2}-\mathrm{NH}_{2}$ nanoparticles quenching the magnetic moment. Although the superparamagnetic behaviors of the magnetic combi-CLEAs displayed decreasing manner, they were well dispersed in phosphate buffered saline (PBS) (Figure 3b) and the superparamagnetic properties were high enough to make easy separation from liquid media (about $10 \mathrm{~s}$ ) in the present of an external magnetic field (Figure 3c), suggesting the as-synthesized magnetic combi-CLEAs could be efficiently applied in asymmetric synthesis of $(R)$-3-quinuclidinol.
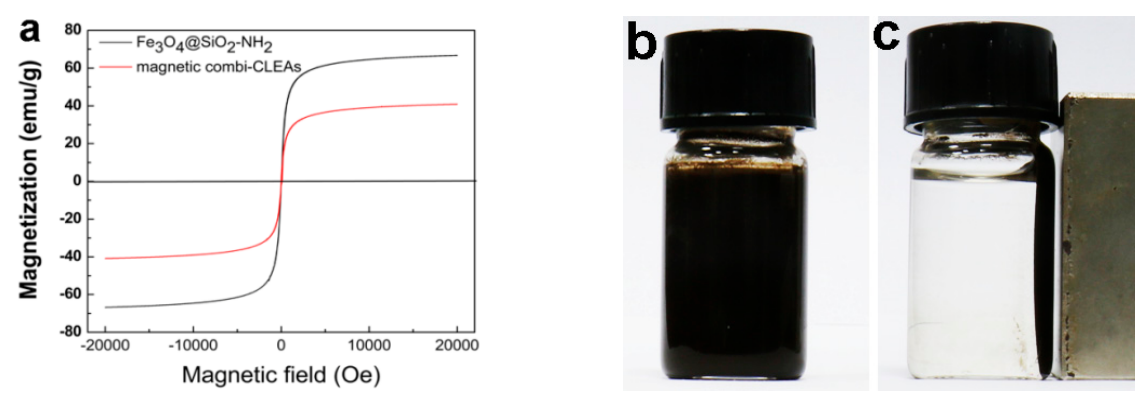

Figure 3. (a) Magnetic hysteresis curves of $\mathrm{Fe}_{3} \mathrm{O}_{4} @ \mathrm{SiO}_{2}-\mathrm{NH}_{2}$ and magnetic combi-CLEAs, (b) PBS-dispersivity of the magnetic combi-CLEAs and (c) the collection of the magnetic combi-CLEAs by an external magnetic field. 
TEM images (Figure 4a) suggested that nearly monodisperse $\mathrm{Fe}_{3} \mathrm{O}_{4} @ \mathrm{SiO}_{2}-\mathrm{NH}_{2}$ nanoparticles were successfully prepared and the average size was about $50 \mathrm{~nm}$. A relatively smooth surface was obtained because of silica coating. Compared with these bare particles, it was obviously observed that combi-CLEAs were inlayed within magnetic nanoparticles (The combi-CLEAs embedded in the nanoparticles was indicated by the red arrow), clearly showing a well-defined spherical appearance (Figure $4 \mathrm{~b}$ ). Based on morphology, the magnetic combi-CLEAs are classified as type 1 which permit better mass transfer. Furthermore, the surface of the magnetic combi-CLEAs showed relatively high numbers of perforations that might facilitate the substrates/cofactors transfer, leading to superior catalytic efficiency.
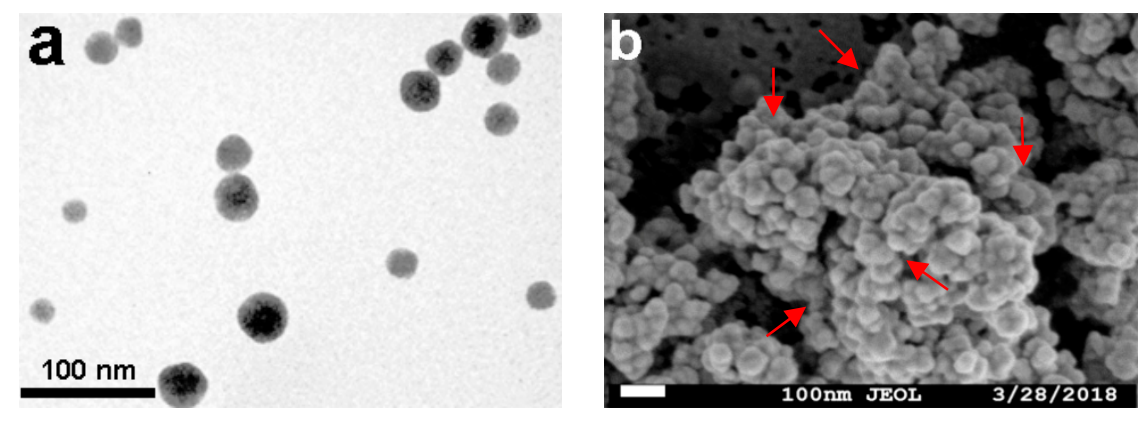

Figure 4. (a) TEM images of the $\mathrm{Fe}_{3} \mathrm{O}_{4} @ \mathrm{SiO}_{2}-\mathrm{NH}_{2}$ and (b) FE-SEM images of the magnetic combi- CLEAs.

\subsection{Screening of Precipitant Agents for Magnetic Combi-CLEAs Preparation}

Activity recovery of the immobilized enzyme is a key cost determining parameter of CLEAs. To preserve the maximum enzyme activity in magnetic combi-CLEAs, it is essential to optimize different parameters for the preparation of magnetic combi-CLEAs. Firstly, an efficient precipitation of all enzymes in its active form is of significant importance in the preparation of magnetic combi-CLEAs. Therefore, five precipitants including ammonium sulfate, acetone, ethanol, isopropanol, DMSO were tested to evaluate their abilities of precipitating QNR and GDH. After the formation of physical aggregates, the precipitate was redissolved, then the remaining activities were measured. Figure 5 showed ammonium sulfate acting as the best precipitating agent compared to four organic solvents, and $97.2 \%$ and $98.5 \%$ of recovered activity was respectively achieved for QNR and GDH, which agrees with previous studies [47,48]. Ammonium sulfate was the best option because it can usually preserve the enzyme activity of the biocatalyst $[47,48]$. While ethanol, isopropanol, DMSO and acetone exhibited relatively lower the recovered activity: $35.3 \%$ and $27.6 \%, 58.7 \%$ and $36.1 \%, 54.8 \%$ and $57.9 \%$, and $85.6 \%$ and $76.2 \%$ for QNR and GDH, respectively. Therefore, ammonium sulfate was chosen as precipitant agent for further magnetic combi-CLEAs preparation.

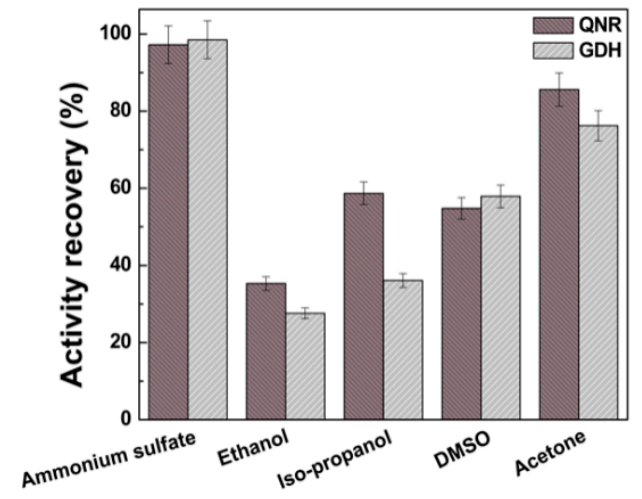

Figure 5. Effect of precipitants on activity recovery of the magnetic combi-CLEAs. The measurements were performed in triplicate. 


\subsection{Effect of Cross-Linker Concentration and Cross-linking Time on Activity Recovery of Magnetic Combi-CLEAs}

GA is a bialdehyde functional molecule commonly used as a cross-linking reagent to prepare CLEAs. However, it is important to note that if too little cross-linker and cross-linking time are not enough to form CLEAs that leads to leaching of enzyme molecules, while too much cross-linker and cross-linking time can cause the destruction of enzyme's flexibility which is essential for its activity $[39,49,50]$. To preserve maximum enzyme activity in the biocatalysts, therefore, we optimized the concentration of cross-linker and cross-linking time. As shown in Figure 6, the activity recovery of QNR and GDH in the magnetic combi-CLEAs was increased with increase in GA concentration and cross-linking time and over $93 \%$ activity recovery for the two enzymes was obtained at $20 \mathrm{mM} \mathrm{GA}$ and $3 \mathrm{~h}$ cross-linking time. Therefore, in the further optimization of magnetic combi-CLEAs preparation process, $20 \mathrm{mM} \mathrm{GA}$ and $3 \mathrm{~h}$ cross-linking time were determined as the optimal conditions.
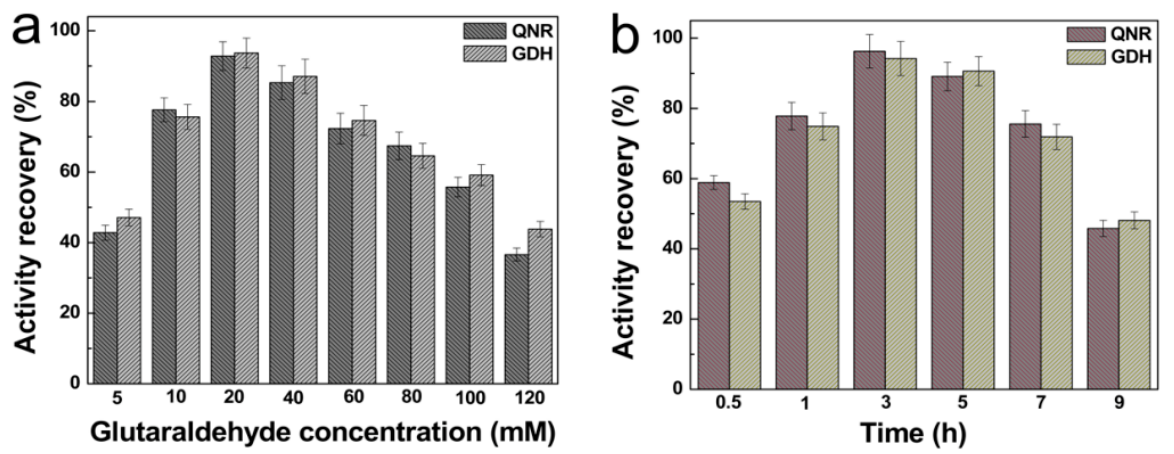

Figure 6. Effect of GA concentration (a) and cross-linking time (b) on the activity recovery of QNR and GDH in the magnetic combi-CLEAs. The measurements were performed in triplicate.

\subsection{Optimal $\mathrm{pH}$ and Temperature for Magnetic Combi-CLEAs Activity Recovery}

The influence of $\mathrm{pH}$ on enzyme activity was investigated in the range from 5.0 to 10.0 at $25^{\circ} \mathrm{C}$. As can be seen from Figure 7a, for the free enzyme the optimized $\mathrm{pH}$ was at 7.0, which shifted to $\mathrm{pH} 8.0$ for the magnetic combi-CLEAs. The shift in $\mathrm{pH}$ could be due to the change in acidic and basic amino acid side chain ionization in the microenvironment around the active site, and the interaction between the enzyme and cross-linking agent [51]. In addition, the relative activity of magnetic combi-CLEAs was always kept higher than those of free enzyme at various $\mathrm{pH}$ value. Nevertheless, at $\mathrm{pH}$ 9.0-10.0 both the free enzyme and the magnetic combi-CLEAs had significant loss of activity, but the activity of the latter decreases slower than the former. The influence of temperature on the relative activity of the free enzyme and the magnetic combi-CLEAs was monitored by measuring enzyme activity as a function of temperature between 15 and $50{ }^{\circ} \mathrm{C}$ after $4 \mathrm{~h}$ incubation. The optimum temperature of the former was $25^{\circ} \mathrm{C}$, whereas the latter showed highest activity at $30^{\circ} \mathrm{C}$ (Figure $7 \mathrm{~b}$ ). Nevertheless, the relative activity of both the free enzyme and the magnetic combi-CLEAs was gradually decreased with further increase in temperature, but the activity of the latter still decreases slower than the former. The data suggested that the magnetic combi-CLEAs had contributed to the resilience of the enzyme against high temperature, which agreed with the results obtained by XRD analysis. This was probably due to the fact that the $\mathrm{Fe}_{3} \mathrm{O}_{4} @ \mathrm{SiO}_{2}-\mathrm{NH}_{2}$ nanoparticles could retarded heat transfer and collapse of the CLEAs structure at test temperatures, and the rigidity of the active conformation was enhanced by cross-linking during the formation of enzyme aggregates [52]. In addition, good storage stability is another essential requirement for a biocatalyst to be employed in industrial applications. The free enzyme and the magnetic combi-CLEAs were stored in PBS at $4{ }^{\circ} \mathrm{C}$ for a 70 days period. Storage stability of the free enzyme and magnetic combi-CLEAs was presented in Figure 7c. The magnetic combi-CLEAs still retained about $80 \%$ of its initial activity after 70 days. However, the free enzyme retained only $28.6 \%$ and $30.5 \%$ of its initial activity for QNR and GDH, respectively. The improved storage stability of 
magnetic combi-CLEAs might be due to the covalent cross-linking between the enzyme aggregates by GA, which avoided enzyme leaching, denaturation and autodigestion, and limited the conformational changes of the enzyme.
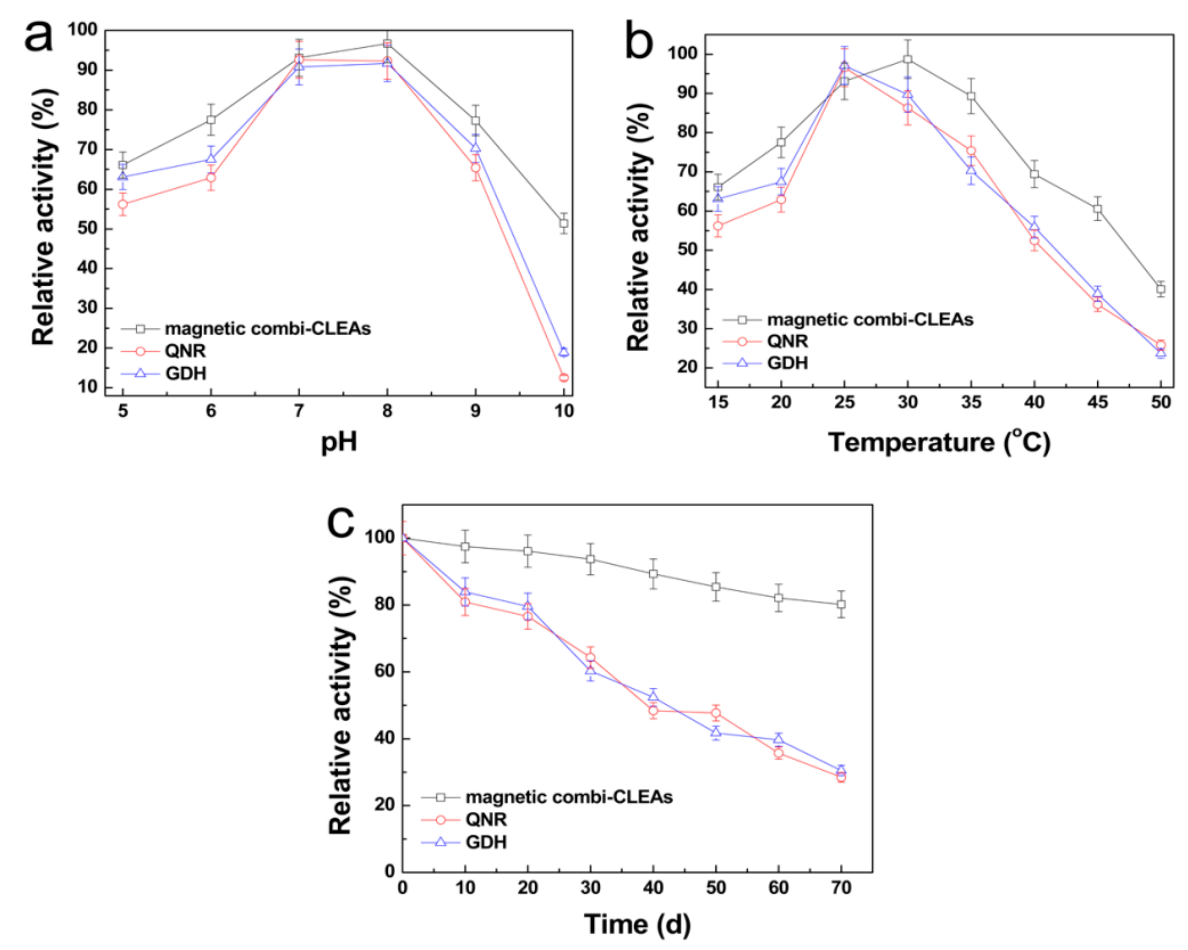

Figure 7. Effect of $\mathrm{pH}$ and temperature on the free enzyme and magnetic combi-CLEAs activity. (a) $\mathrm{pH}$, (b) temperature and (c) storage stability of the free enzyme and magnetic combi-CLEAs. Activity was assayed at $25^{\circ} \mathrm{C}$ in the standard reaction medium at $\mathrm{pH} 7.5-8.0$. The measurements were performed in triplicate.

\subsection{Time-Course of Biosynthesis of (R)-3-quinuclidinol}

The ability of the biocatalysts to catalyze the synthesis of (R)-3-quinuclidinol with substrate-coupled cofactor regeneration was tested (Scheme 2). The biotransformation of 3-quinuclidinone into (R)-3-quinuclidinol was carried out by the free enzyme at $25^{\circ} \mathrm{C}, \mathrm{pH} 7.0$ or by the magnetic combi-CLEAs at $30^{\circ} \mathrm{C}, \mathrm{pH} 8.0$, respectively, and glucose was used as co-substrate. The samples were withdrawn at appropriate intervals from reaction system and analyzed by gas chromatography (GC). The results showed (Figure 8a) that the magnetic combi-CLEAs completely transformed 3-quinuclidinone into the corresponding (R)-3-quinuclidinol with 100\% ee and $100 \%$ conversion yield in $3 \mathrm{~h}$, which is about two times faster than that of free enzyme. The conversion yield and ee value agreed with the pervious reported results $[18,53]$. Three of the employed enzymes, QNR in this study from Microbacterium luteolum JCM9174, ArQR from Agrobacterium radiobacter ECU2556 [18] and RrQR from Rhodotorula rubra [53], were novel enzymes belonging to the short-chain alcohol dehydrogenase/reductase superfamily due to their low amino acid identity between each other. The difference in reaction velocity and reaction time may be due to the difference in the biocatalysts loading, cofactor concentration and enzyme intrinsic property. The intermediate in samples could be also displayed by thin layer chromatography (TLC) and stained by iodine, suggesting that the versatile semi-quantitative method can be used for determining the changes in the concentration of substrate and products in the reaction progress with time(Figure $8 \mathrm{~b}$ for free enzyme, and $\mathrm{c}$ for the magnetic combi-CLEAs). Compared to the ever reports [18,53], The shorter period should be attributed to the fast diffusion of 3-quinuclidinone between QNR and GDH due to the short distance between 
QNR and GDH in the magnetic combi-CLEAs. Hence, co-immobilizing QNR and GDH in magnetic combi-CLEAs is an effective strategy for asymmetric synthesis $(R)$-3-quinuclidinol.

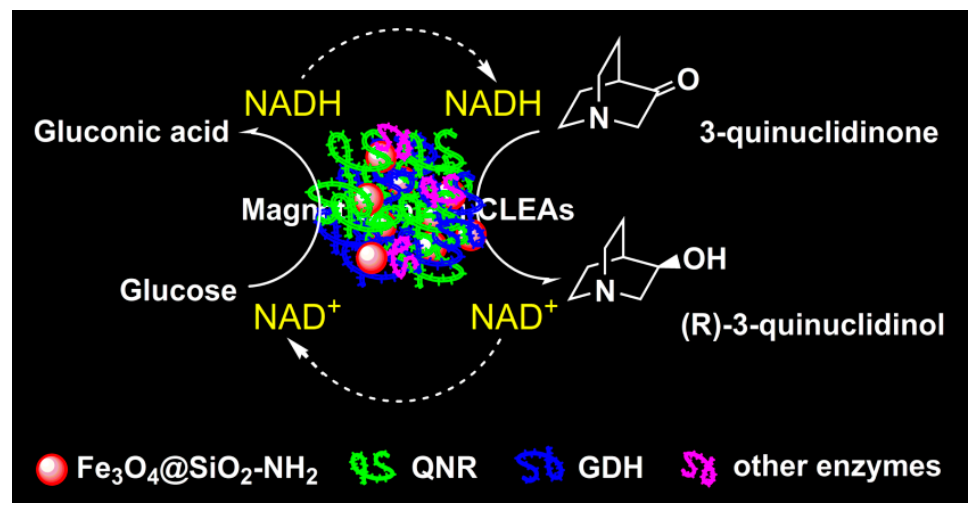

Scheme 2. The magnetic combi-CLEAs biocatalysts for the production of (R)-3-quinuclidinol with cofactor regeneration in situ.
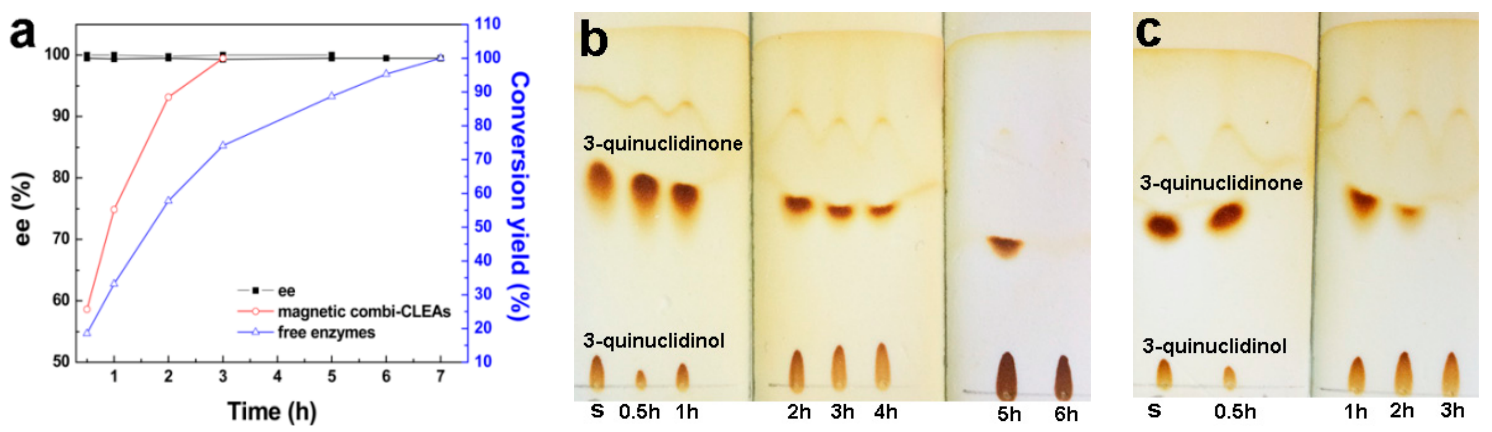

Figure 8. Reaction time-course for the bioreduction of 3-quinuclidinone into ( $R$ )-3-quinuclidinol catalyzed by the free enzyme or the magnetic combi-CLEAs, respectively. Samples $(0.5 \mathrm{~mL})$ were withdrawn at the appropriate intervals and analyzed by GC (a) or by TLC $(\mathbf{b}, \mathbf{c})$.

For applications of ketoreductase, recycling is of significant importance. The main advantage of the magnetic combi-CLEAs is its easy separation from the reaction mixtures. This resulted in a complete recovery of the immobilized enzymes and cost-effective industrial applications [51]. In our experience, the magnetic combi-CLEAs are eminently recyclable. After each cycle, the magnetic combi-CLEAs could be successfully separated from the reaction medium using a magnet, and employed again in the next cycle. As shown in Figure 9a, the magnetic combi-CLEAs biocatalyst was able to cycle up to 10 runs, and the complete conversion time for each run was 3, 3, 3.5, 3.5, 4, 4, 4, 5, 5.5 and $7 \mathrm{~h}$, respectively. After the successive 7th cycle, reduction of $0.33 \mathrm{~g}(2.0 \mathrm{mmol}) 3$-quinuclidinone with $50 \mathrm{mg}$ of the magnetic combi-CLEAs in the presence of $3 \mathrm{mmol}$ of glucose and $6.6 \mathrm{mg}$ reduced nicotinamide adenine dinucleotide $\left(\mathrm{NAD}^{+}\right)$afforded over $100 \%$ conversion efficiency and (R)-3-quinuclidinol in $100 \%$ ee at $300 \mathrm{~min}$. However, at 10 th cycle, it took $420 \mathrm{~min}$ to reach $100 \%$ yield, $180 \mathrm{~min}$ longer than the 7th cycle. The residual activity of the magnetic combi-CLEAs during the reaction cycles was also presented in Figure 9b. It was found that the activity of magnetic combi-CLEAs was well-maintained up to the 7th batch and decreased to approximately $59.1 \%, 54.3 \%$ and $43.5 \%$ of its original activity for QNR, and $60.9 \%, 58.3 \%$ and $45.8 \%$ for GDH at 8,9 and 10 cycles, respectively. The obvious decrease of the catalytic activity after the 7th cycle, especially in the 9th and 10th runs, could be due to the enzyme denaturation, partial collapse of the magnetic combi-CLEAs and substantial leakage from the support into the reaction batch during repeated use. 

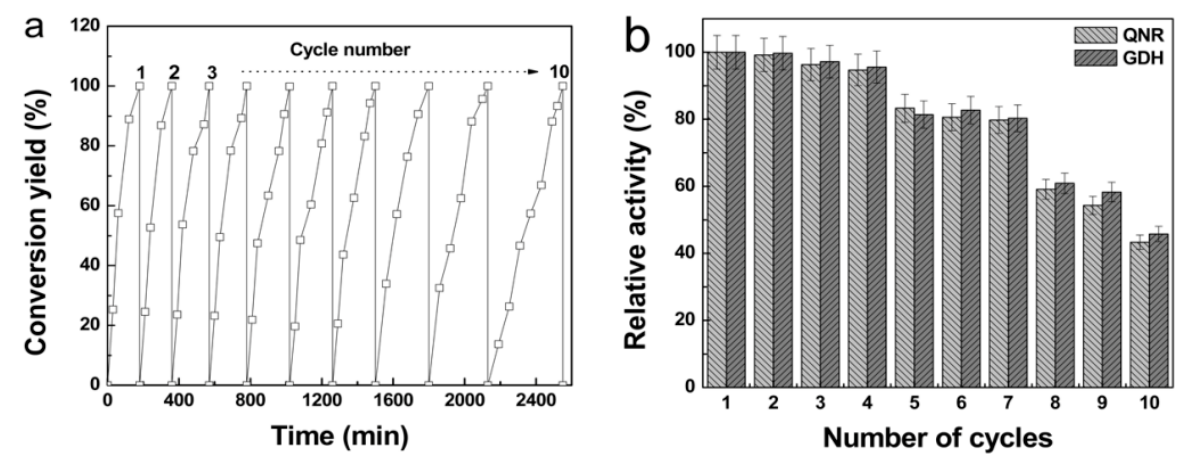

Figure 9. Reusability of magnetic combi-CLEAs for the bioreduction of 3-quinuclidinone into $(R)$-3-quinuclidinol, (a) conversion yield of 3-quinuclidinone and ee of (R)-3-quinuclidinol; (b) relative activity of QNR and GDH in magnetic combi-CLEAs.

In addition, we also utilized the FE-SEM to further investigate the change of the magnetic combi-CLEAs surface structure during the cycles of repeated use. The results revealed that almost no obvious morphologic change was observed, and the magnetic biocatalyst presented a spherical or nearly spherical structure even after the seventh cycle (Figure 10a-g), indicating that the morphologic integrity of the magnetic combi-CLEAs was obviously in close agreement with its enzyme activity (Figure 9b). As can be seen from Figure 10h-j, the eighth, ninth and tenth cycles experienced partial collapse of spherical structure, the disappearance of small hole present on the surface of the magnetic combi-CLEAs and then aggregation into a bigger size of the combi-CLEAs, respectively. Because particle size of the combi-CLEAs can affect mass transfer of the substrates and prevent substrates contacting with the inner enzymes of the combi-CLEAs, the inner enzymes present in the bigger size of the magnetic combi-CLEAs were inaccessible and could not form complexes with the substrates $[48,54]$, hence, leading to the loss of enzyme activity of the magnetic combi-CLEAs. From another point of view, the change in surface structure of magnetic combi-CLEAs supports the value of using combi-CLEAs in combination with the $\mathrm{Fe}_{3} \mathrm{O}_{4} @ \mathrm{SiO}_{2}-\mathrm{NH}_{2}$ to yield magnetic combi-CLEAs with excellent resistance to mechanical stress, such as shake or agitate and wash, allowing high recovery of the biocatalyst after many cycles and providing $(R)$-3-quinuclidinol in high ee and yield.
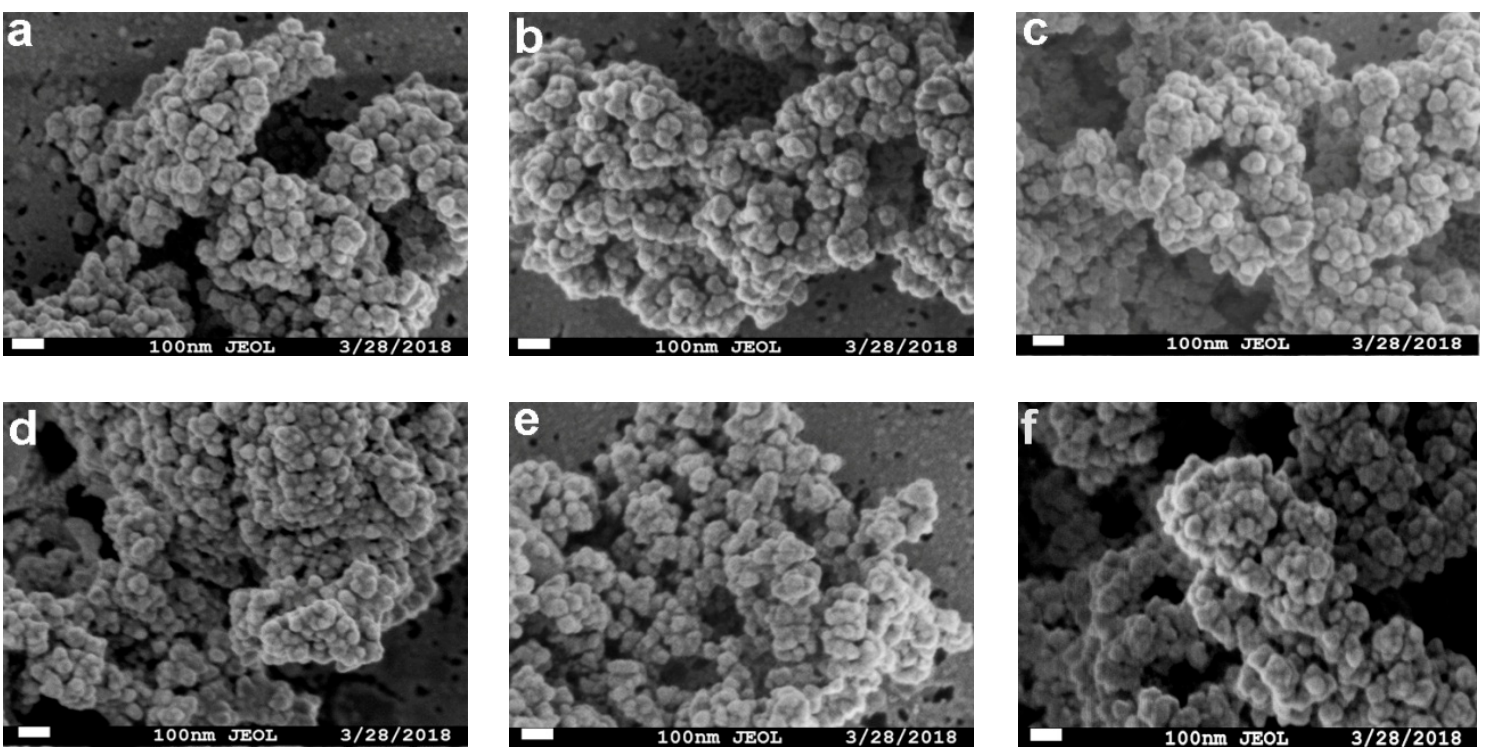

Figure 10. Cont. 

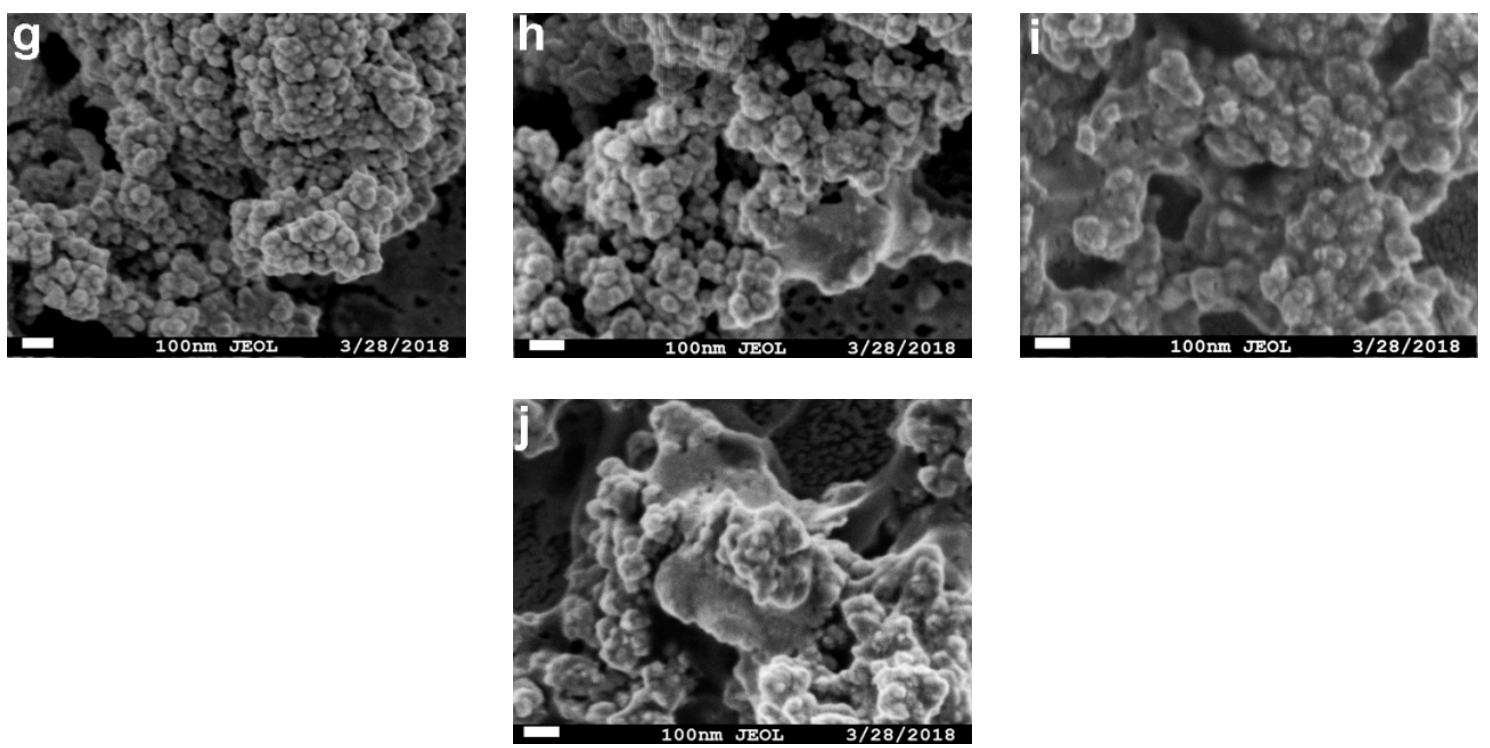

Figure 10. The morphology change of image of the magnetic combi-CLEAs during 10 cycles observed by FE-SEM.

\section{Materials and Methods}

\subsection{Materials}

Recombinant plasmid pET28a-QNR and pET28a-GDH was provided by Taihe (Beijing, China). Competent cells E. coli BL(21) (DE3) was from Tiangen (Beijing, China). Page Ruler Prestained Protein Ladder was form Thermo Fisher Scientific (Waltham, MA, USA). Isopropy-l- $\beta$-D-thiogalactopyranoside (IPTG), 3-aminopropyltriethoxysilane (APTES), Tetraethylorthosilicate (TEOS), all reagents for sodium dodecyl sulfate polyacrylamide gel electrophoresis (SDS-PAGE), 3-quinuclidone and standard (R)-3-quinuclidinol were obtained from Sigma-Aldrich (Shanghai, China). Other chemicals and reagents were the highest purity available. The deionized water was ultrapure produced by Millipore system (Bedford, MA, USA).

\subsection{Expression of Recombinant Enzyme QNR and GDH}

Recombinant plasmid of pET28a-QNR and pET28a-GDH was transformed into competent E. coli $\mathrm{BL}(21)(\mathrm{DE} 3)$, and the resulting cells were respectively denoted as E. coli (QNR) and E. coli (GDH) and cultivated in Luria Broth medium supplemented with $100 \mu \mathrm{g} / \mathrm{mL}$ of kanamycin at $37^{\circ} \mathrm{C}$. The overnight culture was inoculated and grown at $37^{\circ} \mathrm{C}$. Expression of the target enzyme was induced until OD600 reached about 0.6 by adding IPTG up to a final concentration of $0.2 \mathrm{mM}$. Cells growth along with enzyme expression continued for $48 \mathrm{~h}$ at $25^{\circ} \mathrm{C}$. The cells were then pelleted by centrifugation $(12,000 \times g$ for $5 \mathrm{~min})$ at $4{ }^{\circ} \mathrm{C}$, washed using ice PBS, 7.4) and resuspended in $50 \mathrm{~mL}$ PBS per gram wet cells. Then the cells were lysed using XC-CD2500 Ultrasonic Oscillator (Ningbo, China) on ice. The supernatant was collected by centrifugation $(15,000 \times g$ for $20 \mathrm{~min})$ at $4{ }^{\circ} \mathrm{C}$. After filtrated by $0.22 \mu \mathrm{m}$ filter membrane, the supernatant was analyzed by SDS-PAGE and the concentration of the proteins was determined by Bradford protein assay [55].

\subsection{Enzyme Activity Assay}

Enzyme activity was assayed spectrophotometrically at $25^{\circ} \mathrm{C}$ by monitoring the absorbance at $340 \mathrm{~nm}$ corresponding to the change in oxidized nicotinamide adenine dinucleotide (NADH) concentration [17]. $1 \mathrm{~mL}$ of assay mixture was consisted of PBS, $3 \mu \mathrm{mol}$ 3-quinuclidinone and $0.3 \mu \mathrm{mol}$ NADH for QNR (or $10 \mu \mathrm{mol}$ glucose and $1 \mu \mathrm{mol} \mathrm{NAD}^{+}$for GDH), and an appropriate amount of QNR 
or GDH. In the case of the magnetic combi-CLEAs, the magnetic biocatalysts were separated using a magnet from the reaction mixture and then the appearance of NADH was measured. One unit of QNR or GDH activity was defined as the amount of enzyme that catalyzed $1 \mu \mathrm{mol} \mathrm{NADH}$ or $\mathrm{NAD}^{+}$per minute. All experiments were performed in triplicates.

\subsection{Immobilization of $Q N R$ and $G D H$}

\subsubsection{Preparation of $\mathrm{NH}_{2}$-Functionalized $\mathrm{Fe}_{3} \mathrm{O}_{4}$ Nanoparticles $\left(\mathrm{Fe}_{3} \mathrm{O}_{4} @ \mathrm{SiO}_{2}-\mathrm{NH}_{2}\right)$}

Magnetic $\mathrm{Fe}_{3} \mathrm{O}_{4}$ nanoparticles were prepared according to the pervious reported method [56]. In brief, $0.27 \mathrm{~g} \mathrm{FeCl}_{3} \cdot 6 \mathrm{H}_{2} \mathrm{O}$ and $0.72 \mathrm{~g} \mathrm{NaAc}$ dissolved in $10 \mathrm{~mL}$ of ethylene glycol under stirring. Then the resulting yellow solution was further treated at $20{ }^{\circ} \mathrm{C}$ for $10 \mathrm{~h}$ in the Teflon-sealed autoclaves. The final products were washed with ethanol and water several times, used freshly or dried by vacuum freeze-drying. To functionalize the $\mathrm{Fe}_{3} \mathrm{O}_{4}$ nanoparticles with $-\mathrm{NH}_{2}$ groups, $100 \mathrm{mg}$ of freshly prepared $\mathrm{Fe}_{3} \mathrm{O}_{4}$ nanoparticles were homogeneously dispersed in $100 \mathrm{~mL}$ mixture solution containing ethanol and water in a volume ratio of $4: 1$ and $1 \mathrm{~mL}$ of concentrated $\mathrm{NH}_{3} \cdot \mathrm{H}_{2} \mathrm{O} .100 \mu \mathrm{L}$ of TEOS was added and the mixture was allowed to react with vigorous stirring for $6.0 \mathrm{~h}$ at $50{ }^{\circ} \mathrm{C}$. The resulting $\mathrm{Fe}_{3} \mathrm{O}_{4} @ \mathrm{SiO}_{2}$ nanoparticles were separated by a magnetic field, washed and redispersed in a mixed solution containing ethanol and water in a volume ratio of $3: 4$ and $1 \mathrm{~mL}$ concentrated $\mathrm{NH}_{3} \cdot \mathrm{H}_{2} \mathrm{O}$, followed by the drop-wise addition of $300 \mu \mathrm{L}$ APTES with vigorous stirring. After $6 \mathrm{~h}$, the precipitate was washed and denoted as $\mathrm{Fe}_{3} \mathrm{O}_{4} @ \mathrm{SiO}_{2}-\mathrm{NH}_{2}$ nanoparticles.

\subsubsection{Preparation of Magnetic Combi-CLEAs of QNR and GDH}

Magnetic combi-CLEAs of QNR and GDH were prepared according the pervious reported method [37]. Typically, $10 \mathrm{mg} \mathrm{Fe} \mathrm{O}_{4} @ \mathrm{SiO}_{2}-\mathrm{NH}_{2}$ nanoparticles were incubated with $2 \mathrm{~mL}$ of the cell lysate containing same units of QNR and GDH (total protein concentration was $4.5 \mathrm{mg} / \mathrm{mL}$ ) in the presence of precipitant agents with continuous shaking at $4{ }^{\circ} \mathrm{C}$ for $30 \mathrm{~min}$ to complete precipitate enzymes. Then chilled GA was added up to the appropriate concentration and the stirring continued for $3 \mathrm{~h}$ at $4{ }^{\circ} \mathrm{C}$. The pellets were collected using magnetic field. Unreacted GA and unbound enzymes were removed by washing with PBS. The final magnetic combi-CLEAs obtained were kept in PBS at $4{ }^{\circ} \mathrm{C}$. The effects of precipitants $\left(\left(\mathrm{NH}_{4}\right)_{2} \mathrm{SO}_{4}\right.$, isopropanol, ethanol, DMSO and acetone), GA concentration and cross-linking time on the activity recovery were tested. The activity recovery of QNR and GDH in the magnetic combi-CLEAs was determined by following equation $[40,47]$.

$$
\text { Activity recovery }(\%)=\frac{\text { Total activity of each enzyme in magnetic combi-CLEAs }(U)}{\text { Total starting activity of each enzyme used for magnetic combi-CLEAs }(U)} \times 100
$$

Subsequently, the influence of $\mathrm{pH}$ and temperature on magnetic combi-CLEAs activities was also studied.

\subsection{Application of Magnetic Combi-CLEAs for Biosynthesis (R)-3-quinuclidinol}

To test the ability of the biocatalysts to biotransform 3-quinuclidone to (R)-3-quinuclidinol, the reaction was carried out as follows: $50 \mathrm{mg}$ magnetic combi-CLEAs, $0.33 \mathrm{~g}$ 3-quinuclidinone $(2.0 \mathrm{mmol}), 0.54 \mathrm{~g}$ glucose $(3.0 \mathrm{mmol}), 6.6 \mathrm{mg} \mathrm{NAD}{ }^{+}$were mixed in $10 \mathrm{~mL}$ of PBS. The reaction system was incubated at $25^{\circ} \mathrm{C}$ with continuous stirring at $100 \mathrm{rpm}$ and the $\mathrm{pH}$ was maintained at 7.5-8.0 by titrating $5 \mathrm{M} \mathrm{NaOH}$. Aliquots $(0.5 \mathrm{~mL})$ were withdrawn at $0.5,1,2,3,4,5$ and $6 \mathrm{~h}$, respectively, the conversion of 3-quinuclidone was monitored TLC analysis. Silica gel coated plates were activated at $110{ }^{\circ} \mathrm{C}$ for $30 \mathrm{~min}$ and $1 \mu \mathrm{L}$ samples were applied. The mixtures of $\mathrm{CH}_{2} \mathrm{Cl}_{2}$ and $\mathrm{CH}_{3} \mathrm{OH}(9: 1, v / v)$ was selected as the eluting solution. The resulting chromatography plates were air dried, and stained with iodine. The ee value and conversion yield of 3-quinuclidone was determined by GC according to the previous report [57]. After the reaction completed, the magnetic combi-CLEAs were collected using magnet and washed with PBS. 


\subsection{Reusability of Enzymes in Magnetic Combi-CLEAs}

To estimate the reusability of magnetic combi-CLEAs to produce (R)-3-quinuclidinol under the same reaction conditions as described above, the biocatalysts were recovered with a magnet after each run, washed twice with PBS, and reused again for the next assay cycle. The retained enzyme activity was compared according to that of initial magnetic combi-CLEAs, which was defined as $100 \%$.

\subsection{Characterization}

The morphology and size of the $\mathrm{Fe}_{3} \mathrm{O}_{4} @ \mathrm{SiO}_{2}-\mathrm{NH}_{2}$ nanoparticles and the magnetic combi-CLEAs were determined by TEM (JEM-1400 plus Electron Microscope, JEOL, Tokyo, Japan) and FE-SEM (JSM-6700F, Hitachi High-Technologies, JEOL, Tokyo, Japan), respectively. FTIR analysis of $\mathrm{Fe}_{3} \mathrm{O}_{4}$, $\mathrm{Fe}_{3} \mathrm{O}_{4} @ \mathrm{SiO}_{2}-\mathrm{NH}_{2}$, free enzyme and magnetic combi-CLEAs were carried out on a Thermo Nicolet 6700 FTIR spectrometer (Madison, WI, USA) at a resolution of $4 \mathrm{~cm}^{-1}$ over the wavelength range $4000-400 \mathrm{~cm}^{-1}$ under transmission mode. XRD measurements were conducted on a DX-1000 X-ray diffractometer (Dandong Fanyuan Instrument Co. LTD, Liaoning, China) to investigate the crystal structure by use of copper $\mathrm{K} \alpha(\lambda=0.154056 \mathrm{~nm})$ as the source of radiation. The sample were scanned in the $2 \theta$ range between $3^{\circ}$ and $80^{\circ}$ at $2^{\circ} / \mathrm{min}$ with a scan step of $0.02^{\circ}$ and a filament voltage of $40 \mathrm{kV}$ at room temperature. The magnetic properties were determined under a varying magnetic field by VSM using a physical property measurement system DynaCool9 (Quantum, Denver, CO, USA).

\section{Conclusions}

In summary, we successfully fabricated the magnetic combi-CLEAs by co-precipitation followed by cross-linking QNR, GDH and $\mathrm{Fe}_{3} \mathrm{O}_{4} @ \mathrm{SiO}_{2}-\mathrm{NH}_{2}$ nanoparticles. Various preparation conditions were optimized, and the physicochemical properties were characterized. The resulting biocatalysts exhibited high activity retention, improved operational stability and excellent catalytic property for the bioreduction of 3-quinuclidinone to $(R)$-3-quinuclidinol. Moreover, the biocatalysts maintain the superparamagnetic behavior, allowing for easy separation from the reaction medium and reusability for 10 cycles with $100 \%$ ee and 100 conversion yield. Such high catalytic efficiency and excellent magnetic recyclability might make economically viable the application of cost enzymes and thus opens a new horizon for biosynthesis of $(R)$-3-quinuclidinol.

Author Contributions: Y.C., Q.J., Q.C. and W.L. designed the experiments; Y.C., Q.J., L.S., L.Z. and S.L. performed the experiments; L.S., Q.L., L.Z., S.L., M.Y. and W.L. analyzed the data; Y.C., Q.J., Q.C., M.Y. and W.L. wrote the paper.

Funding: This research was funded by Municipal Science and Technology Committee of Chongqing: CSTC2014jcyjA0019.

Acknowledgments: This work was supported by School of Pharmacy, Chongqing Medical University.

Conflicts of Interest: The authors declare no conflict of interest.

\section{References}

1. Breuer, M.; Ditrich, K.; Habicher, T.; Hauer, B.; Keßeler, M.; Stürmer, R.; Zelinski, T. Industrial Methods for the Production of Optically Active Intermediates. Angew. Chem. Int. Ed. 2004, 43, 788-824. [CrossRef] [PubMed]

2. Ramesh, N.P. Synthesis of chiral pharmaceutical intermediates by biocatalysis. Coord. Chem. Rev. 2008, 252, 659-701.

3. Kisukuri, C.M.; Andrade, L.H. Production of chiral compounds using immobilized cells as a source of biocatalysts. Org. Biomol. Chem. 2015, 13, 10086-10107. [CrossRef] [PubMed] 
4. Prat, M.; Fernández, D.; Buil, M.A.; Crespo, M.I.; Casals, G.; Ferrer, M.; Tort, L.; Castro, J.; Monleón, J.M.; Gavaldà, A.; et al. Discovery of Novel Quaternary Ammonium Derivatives of ( $3 R$ )-Quinuclidinol Esters as Potent and Long-Acting Muscarinic Antagonists with Potential for Minimal Systemic Exposure after Inhaled Administration: Identification of (3R)-3-\{[Hydroxy(di-2-thienyl)acetyl]oxy\}-1-(3-phenoxypropyl)1-azoniabicyclo[2.2.2] octane Bromide (Aclidinium Bromide). J. Med. Chem. 2009, 52, 5076-5092. [PubMed]

5. Naito, R.; Yonetoku, Y.; Okamoto, Y.; Toyoshima, A.; Ikeda, K.; Takeuchi, M. Synthesis and Antimuscarinic Properties of Quinuclidin-3-yl 1,2,3,4-Tetrahydroisoquinoline-2-carboxylate Derivatives as Novel Muscarinic Receptor Antagonists. J. Med. Chem. 2005, 48, 6597-6606. [CrossRef] [PubMed]

6. Alabaster, V.A. Discovery \& development of selective M3 antagonists for clinical use. Life Sci. 1997, 60, 1053-1060. [PubMed]

7. Rabe, K.F.; Watz, H. Chronic Obstructive Pulmonary Disease. Lancet 2017, 389, 1931-1940. [CrossRef]

8. Astellas Pharma US Inc. VESIcare Prescribing Information. 2013. Available online: http:/ /www.astellas.us / docs/vesicare.pdf (accessed on 19 October 2016).

9. Marsh, K.; Zaiser, E.; Orfanos, P.; Salverda, S.; Wilcox, T.; Sun, S.; Dixit, S. Evaluation of COPD Treatments: A Multicriteria Decision Analysis of Aclidinium and Tiotropium in the United States. Value Health 2017, 20, 132-140. [CrossRef] [PubMed]

10. Tsutsumi, K.; Katayama, T.; Utsumi, N.; Murata, K.; Arai, N.; Kurono, N.; Ohkuma, T. Practical Asymmetric Hydrogenation of 3-Quinuclidinone Catalyzed by the XylSkewphos/PICA-Ruthenium(II) Complex. Org. Process Res. Dev. 2009, 13, 625-628. [CrossRef]

11. Arai, N.; Akashi, M.; Sugizaki, S.; Ooka, H.; Inoue, T.; Ohkuma, T. Asymmetric Hydrogenation of Bicyclic Ketones Catalyzed by BINAP/IPHAN-Ru(II) Complex. Org. Lett. 2010, 12, 3380-3383. [CrossRef] [PubMed]

12. Nomoto, F.; Hirayama, Y.; Ikunaka, M.; Inoue, T.; Otsuka, K. A practical chemoenzymatic process to access (R)-quinuclidin-3-ol on scale. Tetrahedron Asymmetry 2003, 14, 1871-1877. [CrossRef]

13. Patel, R.N. Biocatalysis: Synthesis of chiral intermediates for drugs. Curr. Opin. Drug Discov. Dev. 2006, 9, 741-764.

14. Zhao, H. Highlights of Biocatalysis and Biomimetic Catalysis. ACS Catal. 2011, 1, 1119-1120. [CrossRef]

15. Wang, Y.; Li, J.; Wu, Q.; Zhu, D. Microbial stereospecific reduction of 3-quinuclidinone with newly isolated Nocardia sp. and Rhodococcus erythropolis. J. Mol. Catal. B Enzym. 2013, 88, 14-19. [CrossRef]

16. Kolet, S.P.; Jadhav, D.D.; Priyadarshini, B.; Swarge, B.N.; Thulasiram, H.V. Fungi mediated production and practical purification of (R)-(-)-3-quinuclidinol. Tetrahedron Lett. 2014, 55, 5911-5914. [CrossRef]

17. Isotani, K.; Kurokawa, J.; Suzuki, F.; Nomoto, S.; Negishi, T.; Matsuda, M.; Itoh, N. Gene Cloning and Characterization of Two NADH-Dependent 3-Quinuclidinone Reductases from Microbacterium luteolum JCM 9174. Appl. Environ. Microbiol. 2012, 79, 1378-1384. [CrossRef] [PubMed]

18. Zhang, W.-X.; Xu, G.-C.; Huang, L.; Pan, J.; Yu, H.-L.; Xu, J.-H. Highly Efficient Synthesis of (R)-3-Quinuclidinol in a Space-Time Yield of $916 \mathrm{~g} \mathrm{~L}^{-1} \mathrm{~d}^{-1}$ Using a New Bacterial Reductase Ar QR. Org. Lett. 2013, 15, 4917-4919. [CrossRef] [PubMed]

19. Wildeman, S.M.A.D.; Sonke, T.; Schoemaker, H.E.; May, O. Biocatalytic Reductions: From Lab Curiosity to "First Choice". Acc. Chem. Res. 2007, 40, 1260-1266. [CrossRef] [PubMed]

20. Reetz, M.T. Biocatalysis in Organic Chemistry and Biotechnology: Past, Present, and Future. J. Am. Chem. Soc. 2013, 135, 12480-12496. [CrossRef] [PubMed]

21. Ngo, T.P.N.; Li, A.; Tiew, K.W.; Li, Z. Efficient transformation of grease to biodiesel using highly active and easily recyclable magnetic nanobiocatalyst aggregates. Bioresour. Technol. 2013, 145, 233-239. [CrossRef] [PubMed]

22. Ngo, T.P.N.; Zhang, W.; Wang, W.; Li, Z. Reversible clustering of magnetic nanobiocatalysts for high-performance biocatalysis and easy catalyst recycling. Chem. Commun. 2012, 48, 4585. [CrossRef] [PubMed]

23. Wang, W.; Xu, Y.; Wang, D.I.C.; Li, Z. Recyclable Nanobiocatalyst for Enantioselective Sulfoxidation: Facile Fabrication and High Performance of Chloroperoxidase-Coated Magnetic Nanoparticles with Iron Oxide Core and Polymer Shell. J. Am. Chem. Soc. 2009, 131, 12892-12893. [CrossRef] [PubMed]

24. Wang, W.; Wang, D.I.C.; Li, Z. Facile fabrication of recyclable and active nanobiocatalyst: Purification and immobilization of enzyme in one pot with Ni-NTA functionalized magnetic nanoparticle. Chem. Commun. 2011, 47, 8115-8117. [CrossRef] [PubMed] 
25. Cassimjee, K.E.; Kourist, R.; Lindberg, D.; Larsen, M.W.; Thanh, N.H.; Widersten, M.; Bornscheuer, U.T.; Berglund, P. One-step enzyme extraction and immobilization for biocatalysis applications. Biotechnol. J. 2011, 6, 463-469. [CrossRef] [PubMed]

26. Herdt, A.R.; Kim, B.-S.; Taton, T.A. Encapsulated Magnetic Nanoparticles as Supports for Proteins and Recyclable Biocatalysts. Bioconjug. Chem. 2007, 18, 183-189. [CrossRef] [PubMed]

27. Vahidi, A.K.; Yang, Y.; Ngo, T.P.N.; Li, Z. Simple and Efficient Immobilization of Extracellular His-Tagged Enzyme Directly from Cell Culture Supernatant as Active and Recyclable Nanobiocatalyst: High-Performance Production of Biodiesel from Waste Grease. ACS Catal. 2015, 5, 3157-3161. [CrossRef]

28. Zhou, Y.; Yuan, S.; Liu, Q.; Yan, D.; Wang, Y.; Gao, L.; Han, J.; Shi, H. Synchronized purification and immobilization of his-tagged $\beta$-glucosidase via $\mathrm{Fe}_{3} \mathrm{O}_{4} / \mathrm{PMG}$ core/shell magnetic nanoparticles. Sci. Rep . 2017, 7, 41741. [CrossRef] [PubMed]

29. Kulsharova, G.; Dimov, N.; Marques, M.P.C.; Szita, N.; Baganz, F. Simplified immobilisation method for histidine-tagged enzymes in poly(methyl methacrylate) microfluidic devices. New Biotechnol. 2017. [CrossRef] [PubMed]

30. Mateo, C.; Fernández-Lorente, G.; Cortes, E.; Garcia, J.L.; Fernandez-Lafuente, R.; Guisan, J.M. One-step purification, covalent immobilization, and additional stabilization of poly-His-tagged proteins using novel heterofunctional chelate-epoxy supports. Biotechnol. Bioeng. 2001, 76, 269-276. [CrossRef] [PubMed]

31. Sheldon, R.A.; Pereira, P.C. Biocatalysis engineering: The big picture. Chem. Soc. Rev. 2017, 46, $2678-2691$. [CrossRef] [PubMed]

32. Sheldon, R.A.; van Pelt, S. Enzyme immobilisation in biocatalysis: Why, what and how. Chem. Soc. Rev. 2013, 42, 6223-6235. [CrossRef] [PubMed]

33. Hiroshi, Y.; Yuhei, K.; Masaya, M. Techniques for Preparation of Cross-Linked Enzyme Aggregates and Their Applications in Bioconversions. Catalysts 2018, 8, 174.

34. Garcia-Galan, C.; Berenguer-Murcia, Á.; Fernandez-Lafuente, R.; Rodrigues, R.C. Potential of Different Enzyme Immobilization Strategies to Improve Enzyme Performance. Adv. Synth. Catal. 2011, 353, 2885-2904. [CrossRef]

35. Samoylova, Y.V.; Sorokina, K.N.; Piligaev, A.V.; Parmon, V.N. Preparation of Stable Cross-Linked Enzyme Aggregates (CLEAs) of a Ureibacillus thermosphaericus Esterase for Application in Malathion Removal from Wastewater. Catalysts 2018, 8, 154. [CrossRef]

36. Dal Magro, L.; Hertz, P.F.; Fernandez-Lafuente, R.; Klein, M.P.; Rodrigues, R.C. Preparation and characterization of a Combi-CLEAs from pectinases and cellulases: A potential biocatalyst for grape juice clarification. RSC Adv. 2016, 6, 27242-27251. [CrossRef]

37. Ning, C.; Su, E.; Tian, Y.; Wei, D. Combined cross-linked enzyme aggregates (combi-CLEAs) for efficient integration of a ketoreductase and a cofactor regeneration system. J. Biotechnol. 2014, 184, 7-10. [CrossRef] [PubMed]

38. Sheldon, R.A. Enzyme Immobilization: The Quest for Optimum Performance. Adv. Synth. Catal. 2007, 349, 1289-1307. [CrossRef]

39. Dong, T.; Zhao, L.; Huang, Y.; Tan, X. Preparation of cross-linked aggregates of aminoacylase from Aspergillus melleus by using bovine serum albumin as an inert additive. Bioresour. Technol. 2010, 101, 6569-6571. [CrossRef] [PubMed]

40. Talekar, S.; Ghodake, V.; Ghotage, T.; Rathod, P.; Deshmukh, P.; Nadar, S.; Mulla, M.; Ladole, M. Novel magnetic cross-linked enzyme aggregates (magnetic CLEAs) of alpha amylase. Bioresour. Technol. 2012, 123, 542-547. [CrossRef] [PubMed]

41. Bhattacharya, A.; Pletschke, B.I. Magnetic cross-linked enzyme aggregates (CLEAs): A novel concept towards carrier free immobilization of lignocellulolytic enzymes. Enzym. Microb. Technol. 2014, 61-62, 17-27. [CrossRef] [PubMed]

42. Barbosa, O.; Ortiz, C.; Berenguer-Murcia, Á.; Torres, R.; Rodrigues, R.C.; Fernandez-Lafuente, R. Strategies for the one-step immobilization-purification of enzymes as industrial biocatalysts. Biotechnol. Adv. 2015, 33, 435-456. [CrossRef] [PubMed]

43. Fernandez-Lafuente, R. Stabilization of multimeric enzymes: Strategies to prevent subunit dissociation. Enzym. Microb. Technol. 2009, 45, 405-418. [CrossRef] 
44. Reddy, D.H.K.; Wei, W.; Shuo, L.; Song, M.-H.; Yun, Y.-S. Fabrication of Stable and Regenerable Amine Functionalized Magnetic Nanoparticles as a Potential Material for Pt(IV) Recovery from Acidic Solutions. ACS Appl. Mater. Interfaces 2017, 9, 18650-18659. [CrossRef] [PubMed]

45. Fortes, C.C.S.; Daniel-da-Silva, A.L.; Xavier, A.M.R.B.; Tavares, A.P.M. Optimization of enzyme immobilization on functionalized magnetic nanoparticles for laccase biocatalytic reactions. Chem. Eng. Process. 2017, 117, 1-8. [CrossRef]

46. Abdulla-Al-Mamun, M.; Kusumoto, Y.; Zannat, T.; Horie, Y.; Manaka, H. Au-ultrathin functionalized core-shell $\left(\mathrm{Fe}_{3} \mathrm{O}_{4} @ \mathrm{Au}\right)$ monodispersed nanocubes for a combination of magnetic/plasmonic photothermal cancer cell killing. RSC Adv. 2013, 3, 7816-7827. [CrossRef]

47. Talekar, S.; Pandharbale, A.; Ladole, M.; Nadar, S.; Mulla, M.; Japhalekar, K.; Pattankude, K.; Arage, D. Carrier free co-immobilization of alpha amylase, glucoamylase and pullulanase as combined cross-linked enzyme aggregates (combi-CLEAs): A tri-enzyme biocatalyst with one pot starch hydrolytic activity. Bioresour. Technol. 2013, 147, 269-275. [CrossRef] [PubMed]

48. Schoevaart, R.; Wolbers, M.W.; Golubovic, M.; Ottens, M.; Kieboom, A.P.G.; van Rantwijk, F.; van der Wielen, L.A.M.; Sheldon, R.A. Preparation, optimization, and structures of cross-linked enzyme aggregates (CLEAs). Biotechnol. Bioeng. 2004, 87, 754-762. [CrossRef] [PubMed]

49. Matijošyte, I.; Arends, I.W.C.E.; de Vries, S.; Sheldon, R.A. Preparation and use of cross-linked enzyme aggregates (CLEAs) of laccases. J. Mol. Catal. B Enzym. 2010, 62, 142-148. [CrossRef]

50. Sheldon, R.A. Characteristic features and biotechnological applications of cross-linked enzyme aggregates (CLEAs). Appl. Microbiol. Biotechnol. 2011, 92, 467-477. [CrossRef] [PubMed]

51. Lai, J.-Q.; Hu, Z.-L.; Sheldon, R.A.; Yang, Z. Catalytic performance of cross-linked enzyme aggregates of Penicillium expansum lipase and their use as catalyst for biodiesel production. Process Biochem. 2012, 47, 2058-2063. [CrossRef]

52. Cui, J.; Cui, L.; Jia, S.; Su, Z.; Zhang, S. Hybrid cross-linked lipase aggregates with magnetic nanoparticles: A robust and recyclable biocatalysis for epoxidation of oleic acid. J. Agric. Food. Chem. 2016, 64, 7179-7187. [CrossRef] [PubMed]

53. Uzura, A.; Nomoto, F.; Sakoda, A.; Nishimoto, Y.; Kataoka, M.; Shimizu, S. Stereoselective synthesis of (R)-3-quinuclidinol through asymmetric reduction of 3-quinuclidinone with 3-quinuclidinone reductase of Rhodotorula rubra. Appl. Microbiol. Biotechnol. 2009, 83, 617-626. [CrossRef] [PubMed]

54. Yu, H.W.; Chen, H.; Wang, X.; Yang, Y.Y.; Ching, C.B. Cross-linked enzyme aggregates (CLEAs) with controlled particles: Application to Candida rugosa lipase. J. Mol. Catal. B Enzym. 2006, 43, 124-127. [CrossRef]

55. Bradford, M.M. A rapid and sensitive method for the quantitation of microgram quantities of protein utilizing the principle of protein-dye binding. Anal. Biochem. 1976, 72, 248-254. [CrossRef]

56. Deng, Y.; Qi, D.; Deng, C.; Zhang, X.; Zhao, D. Superparamagnetic High-Magnetization Microspheres with an $\mathrm{Fe}_{3} \mathrm{O}_{4} @ \mathrm{SiO}_{2}$ Core and Perpendicularly Aligned Mesoporous $\mathrm{SiO}_{2}$ Shell for Removal of Microcystins. J. Am. Chem. Soc. 2008, 130, 28-29. [CrossRef] [PubMed]

57. Yu, M.; Liu, D.; Sun, L.; Li, J.; Chen, Q.; Pan, L.; Shang, J.; Zhang, S.; Li, W. Facile fabrication of 3D porous hybrid sphere by co-immobilization of multi-enzyme directly from cell lysates as an efficient and recyclable biocatalyst for asymmetric reduction with coenzyme regeneration in situ. Int. J. Biol. Macromol. 2017, 103, 424-434. [CrossRef] [PubMed]

(C) 2018 by the authors. Licensee MDPI, Basel, Switzerland. This article is an open access article distributed under the terms and conditions of the Creative Commons Attribution (CC BY) license (http://creativecommons.org/licenses/by/4.0/). 